\title{
Peace Journalism and News Coverage on the Cyprus Conflict
}

\author{
Metin Ersoy \\ Eastern Mediterranean University \\ Cyprus
}

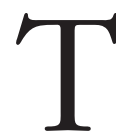

he twentieth and twenty-first centuries seem to have found their place in history, having been the setting of various ethnic conflicts. Ethnic conflicts are alive everywhere in the world and journalists report them. Along with the political spectrum, the media plays either a negative or a positive role in cold or hot conflicts of the world.

"Ethnic conflict is not a phenomenon unique to Cyprus, but a crucial problem for a variety of multi-ethnic states, such as Great Britain, Spain, Russia, Rwanda, former Yugoslavia, etc. The recent tragedies in Kosovo, Bosnia, Rwanda, Chechnya, as well as in other parts of the world constitute a great shame for all humanity due to our evident inability to prevent and solve ethnic conflicts." ${ }^{1}$ The situation in Cyprus is similar.

Due to its geopolitical location, the island of Cyprus bears strategic importance for many countries. Some consider Cyprus an unsinkable aircraft carrier floating in the Mediterranean Sea. Located in the eastern part of the Mediterranean, the island can be described as the middle of the Middle East. There are more than 1 million people currently living on the island. A great majority of the population consists of Orthodox Greek Cypriots and Muslim Turkish Cypriots. Maronites and Armenians of the island have a minority status.

One of the most significant and frequently covered issues in the media of Cyprus and the world for more than half a century is certainly the "Cyprus Conflict." 2 The Cyprus Conflict is the second longest-lasting, consistent conflict of competing nationalisms in the area of the Middle East after the Israeli-Palestinian conflict. The Cyprus Conflict still remains to be resolved.

Communities always feel the need for an investigative, inquisitorial, and critical media that is not monopolized. At this point, it is necessary to question and study the potential impact of the media and journalists on communities as well as their role in inter-communal relations. For example, Daya Kishan Thussu and Des Freedman explained how the media played a vital role and helped to end the US-Vietnam war. "One of the key turning points of the war was the transmission of a special report by the country's most celebrated news anchor, Walter Cronkite of CBS." 3 This example shows 
that the media plays a vital role in the conflict process and also in the de-escalation of that conflict.

Wolfsfeld, in his book the Media and the Path to Peace, states that the Oslo Peace Process is an important example of how the media has escalated the conflict between Palestinians and Israelis. Several studies show the crucial role played by the media during this process. As Wolfsfeld mentioned, "The media emphasized the negative aspects of the process and tended to ignore the more positive developments associated with Oslo."

Wolfsfeld also mentions the constructive role the media has played in the Northern Ireland conflict. He says, "The media environment in Northern Ireland was also more conducive to peace. Citizens from both sides of that conflict used the same news media and this led the press to play a more constructive role." According to Wolfsfeld, the media environment is critical to de-escalating a conflict; however, the political setting does also matter. If the political setting also calls for peace, then the media could change their reporting style from victory-based reporting to a solution-oriented one. ${ }^{6}$ There are several studies explaining the influence of political elites on the media. ${ }^{7}$

While studying the potential roles that can be assumed by the media in intercommunal conflicts, we should not disregard the concept of "Peace Journalism," which emerged in the 1970s. This concept was introduced by a Norwegian scientist named Johan Galtung. Jake Lynch and Annabel McGoldrick, two prominent figures putting Peace Journalism into practice, further developed this notion in 1990 s.

The Peace Journalism approach evolved significantly during the first Gulf War back in the 1990s. It is an approach which questions the role of the media in warfare and conflict zones, and offers criticism of the news value of stories reported in traditional journalism.

This article looks at news stories reported in the Turkish Cypriot and Greek Cypriot papers on matters relating to one another, from the perspective of Peace Journalism. The media of both parties in Cyprus do allocate sizeable coverage for stories related to the Cyprus Conflict. However, it is observed that journalists do not necessarily adhere to the principles of Peace Journalism as they prepare the reporting of newsworthy stories on the conflict.

This study tests the following main hypotheses:

1. Cyprus media (both the Turkish and the Greek Cypriot) news coverage publishes negative headlines about each other;

2. Cyprus media prefers to choose negative stories (such as those involving crime, rape, and drug use, etc.) rather than positive stories in covering news about the Other;

3. The news values of Cypriot journalism are not helping with reconciliation and peace building between the Turkish and the Greek Cypriot communities.

News agencies in Cyprus tend to publish negative stories about the Other while reporting news. It is important to note that the Cypriot media is engaged in elite-centered ("elitist") news reporting. Elite-centered news reporting gives more say to state 
authorities, government officials, politicians and military officials than others. Thus, the media in Cyprus is often a mere tool to convey the message of the elite. However, in reality, the media should be the watchdog over the elite rather than being its agent. Negative statements made by the elite play a significant role in the process of the reporting of negative stories by the media in Cyprus.

The results of this study present the underpinnings of the above-stated hypotheses and conclude that the newsworthy stories covered by the Cypriot media do not contribute to the reconciliation process. The style used in presenting the stories relating to the Other is a conflict-oriented one.

\section{Peace Journalism and the Cypriot Media}

Peace Journalism is a new concept in the academic field and media sector. It is important to stress that Peace Journalism is a new kind of reporting, and involves news selection and news framing in journalism.

"Peace" is a problematic concept and "Peace Journalism" is no less ambiguous, carrying with it all of the conceptual difficulties associated with what "peace" might mean. There is a potential here for misunderstanding the role of the journalist in the Peace Journalism process and thus it is worthwhile to focus some attention on the concept of "Peace Journalism" as it uncovers and reveals the problems associated with the implementation of current mainstream media industry processes and practices. Today, only a few journalists consciously use a Peace Journalism approach, while many others cross between what can be identified as "war" and "peace" oriented journalism without consciously being aware of the contradiction. ${ }^{8}$

Annabel McGoldrick and Jake Lynch interviewed Johan Galtung in Tel Aviv, Israel in 2005, ${ }^{9}$ in order to understand Galtung's rationale for using the term "Peace Journalism." Galtung was working on the structure of foreign news in the early 1960's, and published this research in 1965. The structure of foreign news research was a description of world journalism. Galtung saw some problems within journalistic practice, namely, that all the news has a negative orientation. After completing this research, Galtung asked the next question, which is "what do you change?"; he was thinking "how can we get more peace into the media?" Galtung says, "In the 1960's, the term 'Peace Journalism'10 started being used."11

Peace Journalism can be called simply "good journalism"; however, Galtung preferred using the term "Peace Journalism." Galtung's definition of peace includes "creativity."12 "Creativity" should not be understood solely within a narrow political definition where a conflict is solved only politically. For the media sector, "creativity" points toward a more peace-oriented rather than conflict-oriented information gathering and reporting process. ${ }^{13}$

At the onset of the $21^{\text {st }}$ century, Galtung, ${ }^{14}$ Kempf, ${ }^{15}$ Shinar, ${ }^{16}$ and others (for example, the Austrian Study Center for Peace and Conflict Resolution ${ }^{17}$ and Lynch \& McGoldrick ${ }^{18}$ ) advocated using creative models and training programs to transform the role of media. ${ }^{19}$ 
Galtung, ${ }^{20}$ the most prominent peace researcher, first began using the term "Peace Journalism" in the 1960s. He defines it as follows: "Peace Journalism stands for truth as opposed to propaganda and lies, 'truthful journalism' being, as mentioned, one aspect of Peace Journalism. It is not 'investigative journalism' in the sense of only uncovering lies on 'our' side. The truth aspect in Peace Journalism holds for all sides, just like exploration of conflict formation and giving voice (glasnost) to all." ${ }^{21}$

Galtung stresses the "truth oriented" aspect of Peace Journalism; some scholars similarly describe Peace Journalism. ${ }^{22}$ For instance, Shinar defines Peace Journalism as "good journalism," 23 Lynch and McGoldrick call it "accurate journalism," "post realistic journalism" and "conflict analysis journalism." ${ }^{24}$ Kempf labels it "de-escalation oriented conflict reporting" ${ }^{25}$ and Bandakov ${ }^{26}$ and Shinar ${ }^{27}$ define it as "responsible journalism."

One should know that uncovering absolute truth may not be possible. Human beings have biases to varying extents. People may and often do disagree with one another about what truth is in certain situations. Peace journalists can and should try to be as balanced as possible in pursuing the truth, but they probably cannot be absolutely certain that they have arrived at the "absolute" truth in their conclusions.

Balanced reporting does not mean lack of objectivity; nonetheless, "Objectivity alone, without balance is not helpful; the same holds for balance without objectivity." ${ }^{28}$ The concept of objectivity as described by Galtung shows that objectivity and balance go hand-in-hand; the point is that Galtung accepts objectivity as truth oriented reporting. ${ }^{29}$ Some scholars believe that objectivity is for the journalist; journalists just report the facts without any comment. "If it [objectivity] means 'just reporting the facts' and not taking responsibility for the likely consequences of particular reporting decisions, then it can be deeply damaging." ${ }^{30}$ Alankus stresses that media cannot be objective and explains how this affects news production. It is hard to believe that news is objective when journalists try to describe events for the audience. In the process of describing, the journalist will be affected by his or her ideology, experience, education level and news values. Though journalists try to construct his or her reality in the news, they report in order to describe it for an audience, the fact is that when two journalists cover the same event, the news articles are going to be different from each other. ${ }^{31}$ As Jamieson and Campbell state, "News is gathered, written, edited, produced, and disseminated by human beings who are part of organizations and who have beliefs and values." 32 It is hard to escape these boundaries. As Gans mentions, "Journalists try hard to be objective, but neither they nor anyone else can in the end proceed without values." 33

Neither Galtung does accept the "just reporting the facts" argument and wants to combine objectivity with balanced reporting. According to him, balanced reporting should include three elements:

1. Balance in a conflict means to give attention to all goals of all parties;

2. Balance means to give attention to common people as well as to elites;

3. Balance means to give attention to all phases of a conflict, before, during, after violence. $^{34}$ 
Lynch and McGoldrick define Peace Journalism as "quality" journalism that uses a set of creative tools to include routinely or habitually under-represented perspectives to provide deeper and broader coverage of the news. ${ }^{35}$ Galtung supports Lynch and McGoldrick's views on Peace Journalism; according to Galtung, "Peace Journalism gives a more realistic image of what goes on in the world." 36

As one can ascertain from the Gatekeeping Theory, ${ }^{37}$ there are some news stories that are not reported by journalists or are not selected by editors, meaning that Peace Journalism tries to present the uncovered issues. As Galtung and Vincent stress, "Journalists should focus on visible and invisible effects of violence and conflict" 38 ; it seems that Peace Journalism can be used for any kind of news story and not only for conflict-related stories.

Shinar uses a similar definition and argues that Peace journalists explore and create demands for learning backgrounds and contexts of conflict formation.

Peace Journalism and peace-oriented strategies to be used by the media aim at improving both media representations of reality and how they are perceived by the public. They propose to frame stories in broader, fairer, and more accurate terms as compared to the ones dictated by the biases of the "ratings culture and structure," and of the interests of governments and movements. They explore and create demands for learning backgrounds and contexts of conflict formation in order to make media sources, processes, and effects more relevant. ${ }^{39}$

Shinar's conception of Peace Journalism shows that commercial and traditional media news values are problematic because of "ratings culture and structure." ${ }^{40} \mathrm{Kempf}$ sees traditional media as "escalation-oriented conflictcoverage" and labels Peace Journalism as "de-escalation-oriented conflict coverage." ${ }^{41}$ However, Kempf argues that, "... traditional escalation-oriented conflict coverage has a higher news value than de-escalation-oriented Peace Journalism. Simplification supports the division of the world into 'us' and 'them' and produces a biased opinion, leading to the interpretation of the conflict as a win-lose situation ... and the preference for negativism, personalization, elite nations and elite persons produces a structural frame which divides the world into 'rich' and 'poor' and at the same time into 'good' and 'evil.' " 42

Consequently, Peace Journalism is related to alternative patterns of covering news reports. Differences in expression carry ideological distinctions also and thus differences in representation. ${ }^{43}$ Peace Journalism is an alternative to traditional news reporting and may help reporters cover conflict in a balanced and critical manner, from a multitude of different perspectives.

The first element is the duty of Peace Journalism in relation to solution. Peace journalists should seek some solutions and give voice to all parties in order to find some common ground. The second element is a people-oriented understanding of Peace Journalism. Peace journalists should allow people to talk about their problems. The third element stresses the process-oriented news understanding of Peace Journalism. Traditional journalists tend to indulge in action-based reporting, which focuses on how many 
people died, which bridge was destroyed, etc. On the other hand, the media does not necessarily follow a process to portray negative sides of the conflict that may have been critical before and after the violence being reported took place.

Lynch makes the following definition: "Peace Journalism is a critical realist theory about the reporting of conflict." ${ }^{44}$ He explains critical realist theory with these words: "In a critical realist view, therefore, news should still be seen as a representation of something other than itself - a 'report of the facts,' even though those facts are, in nearly every case, already mediated by the time any journalist, let alone readers and audiences, comes into contact with them." ${ }^{25}$ Lynch's peace Journalism definition does not include pure objectivity of the news. He sees news as constructed information which is gathered by the journalist. During this construction, the journalist cannot be objective because of certain values he or she holds, the socio cultural environment, and media structure.

As Arsan argues in her article titled Catısma ve Savaş Dönemlerinde Gazetecilik (Journalism in Conflict and War Period), "Peace oriented journalism is based on human, truth and solution; considers balance and has a hands-off attitude in the selection of news and use of language; makes the reasons for the problem transparent; establishes empathy with others rather than antagonizing as you and us; tries to prevent violence before it occurs; the emphasis is on the foundations of violence that are not apparent." 46

According to Arsan's definition, it can be said that Peace Journalism is an innovative understanding of the journalism profession, which uses a conflict analysis technique, such as empathy with "others" and understanding, to promote peace. ${ }^{47}$

\section{"If It Bleeds, It Leads" vs. "Healthy, Transparent, Balanced"}

The concept of Peace Journalism has gained impetus since the 1990s. Lesley Fordred Green and Phillip Visser explain the progress of Peace Journalism under four main headings: (i) The roles of journalists; (ii) the style of journalists; (iii) approaches in journalism; and (iv) approaches relating to the target group. ${ }^{48}$ In summary, Green and Visser recommend that journalists assume greater responsibility in news reporting in Peace Journalism as opposed to traditional news reporting.

According to Green and Visser, the role of Peace journalists differs from those that follow traditional news reporting practice in that the journalist is the one that enables and he/she is the one that establishes the necessary connections. The journalist is inherent in the news story he/she is covering. As can be understood from those new roles, Peace journalists - instead of keeping a distance from the stories they cover adopt a new approach of news reporting, which is solution-based and requires their direct involvement. ${ }^{49}$

Traditional news reporting has three striking features. Journalists following the practice of traditional journalism tend to use a style that approaches stories from a negative perspective, focuses on differences and creates controversy. Peace journalists 
prefer a reporting style that establishes dialogue, focuses on common ground along with differences and creates a positive approach. As can be seen, Peace Journalism brings a new style to the news reporting concept, and aims at creating a common ground for parties to discuss possible solutions and start a dialogue.

The third innovation introduced by Lesley Fordred Green and Phillip Visser in the field of news reporting can be summarized as follows: traditional journalists adopt a simple investigation, whereas peace journalists employ the method of meticulous analysis/investigation. ${ }^{50}$ While traditional journalists are reactional to acts of violence, peace journalists make an effort to understand the conflict and reveal its causes. As traditional journalists cover "action" based stories, Peace journalists focus on the "process." 51 In other words, the concept of Peace Journalism is not limited to the lifetime of a conflict or a war, but also covers the stories about the problems of afflicted communities in the post-war period. Traditional journalists consider balanced reporting to be allocating equal coverage to all conflicting parties, whereas Peace journalists take balanced reporting as the covering of stories and presenting the perceptions of both parties.

Traditional journalism and Peace Journalism also differ in terms of their target group, namely, their readers, viewers and audience. ${ }^{52}$ In traditional journalism, news stories about violence and conflict appeal to the target group and do have an influence on them. It is the News Centre that shapes the agenda. Leaders and experts will always know what is best for everybody. Citizens have the right to know. Traditional journalism advocates that this is the only way to report news.

Peace Journalism, however, involves its readers and viewers in problem-solving. Peace Journalism believes in the power of people to set the agenda. It argues that ordinary people might also need guidance. It emphasizes readers' and viewers' right to participate in democracy.

\section{Why Does Peace Journalism Matter in Cyprus Matter?}

The news values employed by the Cyprus media are not ones that can contribute to conflict resolution. As this study clearly indicates, stories relating to the Cyprus Conflict, accidents, robberies, criminal offenses, incriminating statements and libel are what is mostly covered by the Turkish Cypriot and the Greek Cypriot media when it comes to news reporting about the Other.

Journalists in Cyprus, with their accumulated experience in traditional journalism, try to look for the negative, intriguing and abnormal elements in the stories they cover. They also employ this attitude while writing reports, selecting stories and publishing about the Other. As the issue of newsworthiness becomes so problematic, journalists prefer to make their stories interesting and appealing to the reader by covering negative stories about the Other. Such an approach leads journalists to do conflict-based news reporting and prevents them from making any positive contribution to resolution. 
Journalists put their stories into certain ideological frameworks and by doing so they encourage the reader to confine their deliberations to the boundaries of that ideological framework. Hence, the importance of ideology and the language used by journalists as they cover stories about the Other becomes once again obvious.

The news agencies of both communities, which cover stories about one another every single day, can make a positive contribution to conflict resolution if they decide to use the convincing power of the media in a positive manner. At the very least they can stop fanning the flames of potential hatred and clash between the two communities. Given this and bearing in mind the existing problems in the Cypriot media, this author believes Peace Journalism is appropriate for that context.

\section{Cypriot Media Before and After the Annan Plan}

While discussing the Cypriot media, one must take the United Nations' (UN) Kofi Annan Plan into consideration, which had a great impact on the media in Cyprus. The Peace Plan, introduced to the Turkish and the Greek Cypriot communities by UN Secretary General Kofi Annan in November 2003, triggered remarkable changes in the media there.

\section{- Turkish Cypriot Media}

With the exception of Kibris Gazetesi (Cyprus Newspaper), a commercial newspaper with the highest circulation rate, almost all the newspapers operating in North Cyprus are the news agencies of certain political parties. After the Justice and Development Party (AKP) in Turkey became the ruling party in 2003, Turkey started to critically review her Cyprus policy. The European Union perspective has gained momentum both in Turkey and in North Cyprus since the victory of the left-wing Republican Turkish Party's (CTP) in 2003 and general elections in North Cyprus.

Once CTP, which aspired to reach a settlement with Greek Cypriots, took over the government with the support of non-governmental organizations (NGOs), a new era started in North Cyprus politics. In this new era, the Turkish Cypriot media closely followed various pro-settlement and pro-EU demonstrations organized with the support of NGOs. Many newspapers adapted themselves to this pro-EU and pro-settlement outlook, which became evident in the Turkish Cypriot community in 2003 when they revised their ideologies accordingly.

This pacifist attitude on the part of the Turkish Cypriot media, which favors resolution and which had been adopted along with the Annan Plan, has undergone much change since the referendum on the Plan. The Annan Plan was simultaneously voted on by the two communities in separate referenda held on 24 April 2004: 64\% of Turkish Cypriots voted in favor of it and $73 \%$ of Greek Cypriots voted against it. A full-fledged execution of the Plan required the two parties to vote in favor of it. Turkish Cypriots were deeply disappointed by the high percentage of Greek Cypriots who voted against the plan, thus losing their trust in Greek Cypriots. All the negative emotions evoked within the community had their influence on the Turkish Cypriot media as well. 
The Turkish Cypriot papers, which had covered numerous positive stories about Greek Cypriots prior to the Plan, reversed their policy and took a negative direction.

\section{- Greek Cypriot Media}

In the midst of all these positive developments in the North Cyprus media, the Greek Cypriot media closely followed the situation, but did not respond. The Greek Cypriot media kept track of the large-scale peace and pro-settlement demonstrations in North Cyprus in full astonishment, but reported them without changing their traditional policy.

Some of the attributes of the Turkish Cypriot media can also be found in the Greek Cypriot media. Though not a common practice, some of the political parties in South Cyprus also print their own newspapers. Phileleftheros is the newspaper enjoying the highest rate of circulation in South Cyprus without having any connection whatsoever to any political party (similar to Kibris Newspaper in North Cyprus).

There has not been a remarkable obvious change in the Greek Cypriot media from before and after the Annan Plan. The moment the Plan was introduced to the parties, some news agencies were subjected to news embargos, blackouts and censorship imposed by the government. For instance, Günther Verheugen, then the EU Commissioner for Enlargement (who was in favor of the Plan), was denied access to a TV program aired by RIK, the state-owned radio and television corporation of South Cyprus.

While evaluating the Annan Plan in light of their own ideologies, the Greek Cypriot papers failed to go beyond the stated anti-Plan policy of their government. They all chose to stay within the limits of the national policy of the state. Therefore, it is not wrong to describe the Greek Cypriot media as state-oriented or state controlled.

\section{Methodology and Analysis}

In order to learn the news coverage about the Cyprus Conflict and how the Turkish and Greek Cypriot presses are covering the "Other" side, a Content Analysis Coding Schema has been developed.

The Content Analysis Coding Schema has 16 questions related to the news coverage: an evaluation of the headline; quoted sources in the story; the topic of the news article; the framing of the news, and some other technical information such as page number, size of the news, date, etc.

The essential aim of this study is to explore the news coverage of the Turkish/Greek Cypriot media and how each frames the Other within their coverage. This will help in formulating a Peace Journalism approach for journalists in Cyprus.

The Content Analysis Coding Schema will also address the following issues: how do Turkish/Greek Cypriot journalists select headlines (positive, natural, negative), who writes the articles (source of the article), and what are the main news topics?

The samples for this research study were published in May 2006. A Content Analysis Coding Schema was conducted for news articles related to the Cyprus Conflict, Turkey, 
Greece, and Turkish and Greek Cypriots. The selected items ranged between; 446 news items from the Turkish Cypriot newspapers and 309 news items from the Greek Cypriot newspapers.

Five Turkish and five Greek Cypriot newspapers were selected as samples for this study, in order to analyze Turkish/Greek Cypriot press coverage of the Cyprus Conflict. The Greek Cypriot newspapers are Alithia, Haravghi, Phileleftheros, Simerini and Politis; the Turkish Cypriot papers are Kibris, Afrika, Yeni Duzen, Halkin Sesi and Volkan.

Regarding Greek Cypriot newspapers, Alithia has close ties with DISI, the main opposition party. Alithia opposes governmental policies and supports unification initiatives. Alithia can be described as a liberal newspaper. Haravghi, on the other hand, is owned by AKEL, the communist party currently in power in the government and which has opposed the Annan Plan referendum campaign. Phileleftheros is a commercial newspaper with the highest circulation in the South. Politis is an independent newspaper and has the second highest circulation, supporting peace initiatives with columnist contributors from Turkish Cypriots. Simerini can be described as a fanatic right-wing newspaper.

As for the Turkish Cypriot newspapers, the following comments can be made: Kibris has the highest circulation in the North, is highly influential, and supports peace initiatives. Afrika is an opposition paper in the North, and takes an active stance on the Cyprus problem with its columnist contributors from Greek Cypriots. Yeniduzen is owned by the Republican Turkish Party currently in the government of the TRNC, and supports unification of the island. Volkan is a nationalist paper which supports division of the island and promotes a two-state solution. Halkin Sesi is the oldest Turkish language newspaper on the island, privately owned and which can be described as a right-wing newspaper.

\section{Findings}

While investigating the media framing used by Turkish and Greek Cypriot papers on the stories related to the Other from the perspective of Peace Journalism, it is obvious that the Turkish and the Greek Cypriot media are far from fulfilling Peace Journalism criteria.

The following findings have been established in this study: the first hypothesis tested by this study has been RQ1: "Cyprus media (both the Turkish and the Greek Cypriot) news coverage employ negative headlines towards each other."

Before revealing the results of the study, the following evaluation benchmarks used in the process must be explained: (i) Positive (towards the other); (ii) Neutral (descriptive); and (iii) Negative (towards the other). ${ }^{53}$ If the headline of the news includes any positive descriptions of the Other, such as using empathy, or are solution-oriented, etc., it counts as positive. Several examples of positive headlines: "Demetrias'in sergisi Lefkoşahlar fotoğraflarla buluşturdu..." ("The exhibition by 
Demetrias brought together the people of Nicosia"), Yenidüzen newspaper, "Barışa şarkilar yeniden sabnede" (Songs for peace are back on stage), Yenidüzen newspaper.

Neutral headlines can be described as headlines that describe what happened without making any judgment and by giving direct quotations from a source. For example: "Rehn 'Türkiye yükümlülüklerini yerine getirmeli' ("Rehn: Turkey must fulfil its commitments"), Volkan newspaper, "Sabte 10 KL" (Fake 10 Cyprus Pound), Afrika newspaper.

Negative headlines can be categorized as headlines that label the Other as the adversary, portraying distrust towards the Other within a win-lose framework. Examples of negative headlines are: "Güney Kıbrıs, uyussturucu merkezi" (South Cyprus, a safe heaven for drugs), Volkan newspaper, "Kaçırdılar, kabadayılık (zorbalık) yaptılar" (They kidnapped and bullied), Politis newspaper.

The Content Analysis Coding Schema results indicate that the majority of Greek Cypriot newspapers' headlines concerning the Cyprus Conflict, Turkey, and Turkish Cypriots are neutral or descriptive with a percentage of 65.4. The negative headlines (31.1\%) are not to be underestimated. Only 3.6\% of their news headlines were positive.

A clear majority of the Turkish Cypriot newspapers' (72.1\%) headlines on the Cyprus Conflict, Greek, or Greek Cypriots are neutral or descriptive oriented. Another significant result is that $24.9 \%$ of the news headlines are negative towards the Other. Positive headlines are about $2.9 \%$.

As indicated by the results of this schema, the hypothesis reading as "Cyprus media (both the Turkish and the Greek Cypriot) news coverage employ negative headlines towards each other" has been proven. The media operating in both sides of Cyprus prefer neutral and descriptive headlines when they report stories about one another. This result does not suggest impartial, balanced and fair news reporting in Cyprus; to the contrary, it portrays how the media in Cyprus has become a tool, serving the political purposes of the elite. Wording the headlines in a way favored by the elite is not compatible with Peace Journalism. As far as Peace Journalism is concerned, the positive stories covered in the media of both communities did not exceed $4 \%$ of the overall coverage.

When reporting a statement made by the elite about the Other which does not contain any positive elements, the Cypriot media tends to cover the story as it is uttered. In other words, the media neither criticizes the statement of the elite nor questions whether or not the media itself contributes to peace. Given this, the Cypriot media often finds itself stuck between two communities acting as a mere messenger and cannot practice responsible reporting. Responsible reporting includes feeling empowered to criticize and question the statements made by the elite, to give a say to the people facing incrimination in the news coverage, to enrich one's news sources, to put forward factors that might lead to a conflict resolution, and to allocate more coverage to the non-governmental organizations and the people that have concrete proposals for conflict resolution. 
EVALUATION OF THE HEADLINES FOR THE GREEK CYPIOT MEDIA

\begin{tabular}{|c|c|c|c|c|c|}
\hline \multicolumn{2}{|l|}{ NEWSPAPERS } & $\begin{array}{l}\text { Positive } \\
\text { (towards } \\
\text { the other) }\end{array}$ & $\begin{array}{l}\text { Neutral } \\
\text { (descriptive) }\end{array}$ & $\begin{array}{l}\text { Negative } \\
\text { (towards } \\
\text { the other) }\end{array}$ & Total \\
\hline Alithia & $\begin{array}{l}\text { Count } \\
\% \text { within } \mathrm{q} 1\end{array}$ & $\begin{array}{l}2 \\
3.8 \% \\
\end{array}$ & $\begin{array}{l}42 \\
79.2 \%\end{array}$ & $\stackrel{9}{17.0 \%}$ & $\begin{array}{c}53 \\
100.0 \% \\
\end{array}$ \\
\hline Haravghi & $\begin{array}{l}\text { Count } \\
\% \text { within q1 }\end{array}$ & $\begin{array}{l}2 \\
3.5 \%\end{array}$ & $\begin{array}{l}39 \\
68.4 \%\end{array}$ & $\begin{array}{l}16 \\
28.1 \%\end{array}$ & $\begin{array}{c}57 \\
100.0 \%\end{array}$ \\
\hline Phileleftheros & $\begin{array}{l}\text { Count } \\
\% \text { within } \mathrm{q} 1\end{array}$ & $\begin{array}{l}3 \\
3.6 \%\end{array}$ & $\begin{array}{l}49 \\
59.0 \%\end{array}$ & $\begin{array}{l}31 \\
37.3 \%\end{array}$ & $\begin{array}{c}83 \\
100.0 \%\end{array}$ \\
\hline Politis & $\begin{array}{l}\text { Count } \\
\% \text { within } \mathrm{q} 1\end{array}$ & $\begin{array}{l}4 \\
7.3 \% \\
\end{array}$ & $\begin{array}{l}35 \\
63.6 \% \\
\end{array}$ & $\begin{array}{l}16 \\
29.1 \% \\
\end{array}$ & $\begin{array}{c}55 \\
100.0 \% \\
\end{array}$ \\
\hline Simerini & $\begin{array}{l}\text { Count } \\
\% \text { within q1 }\end{array}$ & $\begin{array}{l}0 \\
.0 \%\end{array}$ & $\begin{array}{l}37 \\
60.7 \%\end{array}$ & $\begin{array}{l}24 \\
39.3 \%\end{array}$ & $\begin{array}{c}61 \\
100.0 \%\end{array}$ \\
\hline Total & $\begin{array}{l}\text { Count } \\
\% \text { within q1 }\end{array}$ & $\begin{array}{l}11 \\
3.6 \%\end{array}$ & $\begin{array}{l}202 \\
65.4 \%\end{array}$ & $\begin{array}{l}96 \\
31.1 \%\end{array}$ & $\begin{array}{l}309 \\
100.0 \%\end{array}$ \\
\hline
\end{tabular}

Evaluations of the headlines of Greek Cypriot newspapers on Cyprus Conflict, Turkey, or Turkish Cypriots.

\section{EVALUATION OF THE HEADLINES FOR THE TURKISH CYPIOT MEDIA}

\begin{tabular}{|c|c|c|c|c|c|}
\hline \multicolumn{2}{|l|}{ NEWSPAPERS } & $\begin{array}{l}\text { Positive } \\
\text { (towards } \\
\text { the other) }\end{array}$ & $\begin{array}{l}\text { Neutral } \\
\text { (descriptive) }\end{array}$ & $\begin{array}{l}\text { Negative } \\
\text { (towards } \\
\text { the other) }\end{array}$ & Total \\
\hline Kibris & $\begin{array}{l}\text { Count } \\
\% \text { within q1 }\end{array}$ & $\begin{array}{l}4 \\
3.2 \% \\
\end{array}$ & $\begin{array}{l}91 \\
73.4 \%\end{array}$ & $\begin{array}{l}29 \\
23.4 \%\end{array}$ & $\begin{array}{l}124 \\
100.0 \%\end{array}$ \\
\hline Halkin Sesi & $\begin{array}{l}\text { Count } \\
\% \text { within q1 }\end{array}$ & $\begin{array}{l}2 \\
2.9 \%\end{array}$ & $\begin{array}{l}47 \\
68.1 \%\end{array}$ & $\begin{array}{l}20 \\
29.0 \%\end{array}$ & $\begin{array}{l}69 \\
100.0 \%\end{array}$ \\
\hline Yeni Duzen & $\begin{array}{l}\text { Count } \\
\% \text { within q1 }\end{array}$ & $\begin{array}{l}4 \\
4.4 \% \\
\end{array}$ & $\begin{array}{l}75 \\
82.4 \% \\
\end{array}$ & $\begin{array}{l}12 \\
13.2 \% \\
\end{array}$ & $\begin{array}{l}91 \\
100.0 \% \\
\end{array}$ \\
\hline Volkan & $\begin{array}{l}\text { Count } \\
\% \text { within q1 }\end{array}$ & $\begin{array}{l}0 \\
.0 \% \\
\end{array}$ & $\begin{array}{l}63 \\
61.2 \% \\
\end{array}$ & $\begin{array}{l}40 \\
38.8 \%\end{array}$ & $\begin{array}{l}103 \\
100.0 \%\end{array}$ \\
\hline Afrika & $\begin{array}{l}\text { Count } \\
\% \text { within q1 }\end{array}$ & $\begin{array}{l}3 \\
5.1 \%\end{array}$ & $\begin{array}{l}46 \\
78.0 \%\end{array}$ & $\begin{array}{l}10 \\
16.9 \%\end{array}$ & $\begin{array}{l}59 \\
100.0 \%\end{array}$ \\
\hline Total & $\begin{array}{l}\text { Count } \\
\% \text { within q1 }\end{array}$ & $\begin{array}{l}13 \\
2.9 \%\end{array}$ & $\begin{array}{l}322 \\
72.2 \%\end{array}$ & $\begin{array}{l}111 \\
24.9 \%\end{array}$ & $\begin{array}{l}446 \\
100.0 \%\end{array}$ \\
\hline
\end{tabular}

Evaluations of the headlines of Turkish Cypriot newspapers on Cyprus Conflict, Greece or Greek Cypriots.

According to the Content Analysis Coding Schema results, the news sources used by the Cypriot Media are rather problematic from the perspective of Peace Journalism. Whenever there is a story in the Greek Cypriot media about the Other, $37.74 \%$ of the sources quoted are from the Greek Cypriot elite.

These results indicate that the Greek Cypriot media is not giving a say to non-governmental organizations (2.3\%) and the public (2.3\%), as they give voice mostly 
to elite. Another significant result shows that the Greek Cypriot press does not give space to Turkish Cypriot quoted sources in their news articles. Results signal that a clear majority (83.8\%) of Greek Cypriot newspapers do not have quotations from Turkish Cypriots or Turkish Cypriot sources.

RQ2: "Cyprus media prefers to choose negative stories (such as crime, rape, and drug use, etc.) rather than positive stories in covering news about the Other."

Negative stories about the Other, namely involving criminal offenses, and incidents of rape and drug-related crimes, are frequently covered in the Cypriot media. As mentioned previously, the Cyprus Conflict itself is a priority subject in news reporting, followed by all the aforementioned negative stories. Therefore, the RQ2 hypothesis is partially proven.

When we look at other relevant studies, we can see that giving a priority to a news story with negative content is in fact a global phenomenon in the media. Wolfsfeld argues that, ". . s scholars simply find conflict more exciting than peace." the human being is that we have a reflex to extraordinary things: the basic idea behind this reaction is protection. That's why human beings are interested in conflict news rather than peace news. The media, however, uses this human interest in a negative way. The traditional claim made by the media is that "the public demands to access the kind of news that includes violence and conflict." Even if there is such a demand from the public, Kempf's studies ${ }^{55}$ show how escalation-oriented reporting affects the conflict between the conflicting sides.

According to the Content Analysis Coding Schema results, news related to police, courts, accidents and disasters of the Other side can be put into the category of negative stories. For the Greek Cypriot press, the percentage of all this news is $15.5 \%$. It is remarkable to see a high percentage of news coverage on topics related to the Cyprus Conflict (34.6\%) and Turkey (25.9\%) in the Greek Cypriot newspapers.

As for the Turkish Cypriot newspapers, the percentage of news relating to "police, courts, accidents and disasters of Other side" is $8.5 \%$. It is remarkable to observe a high percentage of news coverage on topics related to the Cyprus Conflict $(47.5 \%)$ and Turkey (36.5\%) in the Turkish Cypriot press as well.

Article topic results, in both the Turkish and the Greek Cypriot media, can be explained in this way. There is general tendency in the Greek Cypriot media to depict Turkey as a basic cause of the Cyprus Conflict. According to Greek Cypriots, the Cyprus problem was started in 1974 when Turkey was still occupying the north side of the island. 25.9\% of news topics are related to Turkey. The Greek Cypriot media tries to prove that Turkey is an occupier of North Cyprus in their news articles.

On the other hand, the Turkish Cypriot media uses 36.5\% of Turkey related news topics. This can be explained in the following way: according to the Turkish Cypriots, Turkey is not occupying North Cyprus; rather, they used their Grantor Rights according to the 1960 Republic of Cyprus Constitution. Consequently, the Turkish Cypriot media tries to respond to the Greek Cypriot media. 
Peace Journalism suggests that responsible reporting by the media can contribute to the settlement of such problems, or at least help in de-escalating them. The Cypriot media constantly portrays the Other side as evil, let alone making a contribution to de-escalating the conflict. The Other is constantly misrepresented to deliver the following message: "We are the good ones, they are the evil ones." Through balanced and fair reporting, Peace Journalism strives to label bad deeds as bad no matter where they take place, without creating any divide such "us" and "them." The third hypothesis of this study focuses on the newsworthiness of stories.

\section{ARTICLE TOPICS FOR THE GREEK CYPIOT MEDIA}

\begin{tabular}{|c|c|c|c|c|c|c|c|c|c|c|c|}
\hline & & $\begin{array}{l}\text { cyprus } \\
\text { conflict }\end{array}$ & $\begin{array}{l}\text { police } \\
\text { and } \\
\text { courts } \\
\text { (other } \\
\text { side) }\end{array}$ & $\begin{array}{l}\text { accidents } \\
\text { and } \\
\text { disasters }\end{array}$ & education & $\begin{array}{l}\text { social } \\
\text { and } \\
\text { cultural } \\
\text { activities }\end{array}$ & economy & sport & Turkey & other & Total \\
\hline Alithia & $\begin{array}{l}\text { Count } \\
\% \text { within q1 }\end{array}$ & $\begin{array}{l}21 \\
39.6 \%\end{array}$ & $\begin{array}{c}7 \\
13.2 \%\end{array}$ & $\begin{array}{l}2 \\
3.8 \%\end{array}$ & $\begin{array}{l}0 \\
.0 \%\end{array}$ & $\begin{array}{l}4 \\
7.5 \%\end{array}$ & $\begin{array}{l}0 \\
.0 \%\end{array}$ & $\begin{array}{l}0 \\
.0 \%\end{array}$ & $\begin{array}{l}12 \\
22.6 \%\end{array}$ & $\begin{array}{c}7 \\
13.2 \%\end{array}$ & $\begin{array}{c}53 \\
100.0 \%\end{array}$ \\
\hline Haravghi & $\begin{array}{l}\text { Count } \\
\% \text { within q1 }\end{array}$ & $\begin{array}{l}23 \\
40.4 \% \\
\end{array}$ & $\begin{array}{c}6 \\
10.5 \% \\
\end{array}$ & $\begin{array}{l}2 \\
3.5 \% \\
\end{array}$ & $\begin{array}{l}1 \\
1.8 \% \\
\end{array}$ & $\begin{array}{l}4 \\
7.0 \% \\
\end{array}$ & $\begin{array}{l}0 \\
.0 \% \\
\end{array}$ & $\begin{array}{l}0 \\
.0 \% \\
\end{array}$ & $\begin{array}{l}16 \\
28.1 \% \\
\end{array}$ & $\begin{array}{l}5 \\
8.8 \% \\
\end{array}$ & $\begin{array}{c}57 \\
100.0 \% \\
\end{array}$ \\
\hline Phileleftheros & $\begin{array}{l}\text { Count } \\
\% \text { within q1 }\end{array}$ & $\begin{array}{l}31 \\
37.3 \%\end{array}$ & $\begin{array}{l}8 \\
9.6 \%\end{array}$ & $\begin{array}{l}5 \\
6.0 \%\end{array}$ & $\begin{array}{l}0 \\
.0 \%\end{array}$ & $\begin{array}{l}2 \\
2.4 \%\end{array}$ & $\begin{array}{l}2 \\
2.4 \%\end{array}$ & $\begin{array}{l}0 \\
.0 \%\end{array}$ & $\begin{array}{l}18 \\
21.7 \%\end{array}$ & $\begin{array}{l}17 \\
20.5 \%\end{array}$ & $\begin{array}{c}83 \\
100.0 \%\end{array}$ \\
\hline Politis & $\begin{array}{l}\text { Count } \\
\% \text { within q1 }\end{array}$ & $\begin{array}{l}20 \\
36.4 \%\end{array}$ & $\begin{array}{l}3 \\
5.5 \%\end{array}$ & $\begin{array}{l}3 \\
5.5 \%\end{array}$ & $\begin{array}{l}1 \\
1.8 \%\end{array}$ & $\begin{array}{l}2 \\
3.6 \%\end{array}$ & $\begin{array}{l}1 \\
1.8 \%\end{array}$ & $\begin{array}{l}1 \\
1.8 \%\end{array}$ & $\begin{array}{l}14 \\
25.5 \%\end{array}$ & $\begin{array}{l}10 \\
18.2 \%\end{array}$ & $\begin{array}{c}55 \\
100.0 \%\end{array}$ \\
\hline Simerini & $\begin{array}{l}\text { Count } \\
\% \text { within q1 }\end{array}$ & $\begin{array}{l}12 \\
19.7 \% \\
\end{array}$ & $\begin{array}{l}6 \\
9.8 \% \\
\end{array}$ & $\begin{array}{l}6 \\
9.8 \% \\
\end{array}$ & $\begin{array}{l}0 \\
.0 \%\end{array}$ & $\begin{array}{l}6 \\
9.8 \%\end{array}$ & $\begin{array}{l}1 \\
1.6 \% \\
\end{array}$ & $\begin{array}{l}0 \\
.0 \% \\
\end{array}$ & $\begin{array}{l}20 \\
32.8 \% \\
\end{array}$ & $\begin{array}{l}10 \\
16.4 \%\end{array}$ & $\begin{array}{c}61 \\
100.0 \% \\
\end{array}$ \\
\hline Total & $\begin{array}{l}\text { Count } \\
\% \text { within q1 }\end{array}$ & $\begin{array}{l}107 \\
34.6 \%\end{array}$ & $\begin{array}{l}30 \\
9.7 \%\end{array}$ & $\begin{array}{l}18 \\
5.8 \%\end{array}$ & $2.6 \%$ & $\begin{array}{l}18 \\
5.8 \%\end{array}$ & $\begin{array}{l}4 \\
1.3 \%\end{array}$ & $\begin{array}{l}1 \\
.3 \%\end{array}$ & $\begin{array}{l}80 \\
25.9 \%\end{array}$ & $\begin{array}{l}49 \\
15.9 \%\end{array}$ & $\begin{array}{l}309 \\
100.0 \%\end{array}$ \\
\hline
\end{tabular}

Article topics within the Greek Cypriot newspapers on the Cyprus Conflict, Turkey or Turkish Cypriots.

\section{ARTICLE TOPICS FOR THE TURKISH CYPIOT MEDIA}

\begin{tabular}{|c|c|c|c|c|c|c|c|c|c|}
\hline & & $\begin{array}{l}\text { cyprus } \\
\text { conflict }\end{array}$ & $\begin{array}{l}\text { police } \\
\text { and } \\
\text { courts } \\
\text { (other } \\
\text { side) }\end{array}$ & $\begin{array}{l}\text { accidents } \\
\text { and } \\
\text { disasters }\end{array}$ & education & $\begin{array}{l}\text { social and } \\
\text { cultural } \\
\text { activities }\end{array}$ & economy & Turkey & Total \\
\hline Kibris & $\begin{array}{l}\text { Count } \\
\% \text { within } \mathrm{q} 1\end{array}$ & $\begin{array}{l}63 \\
50.8 \%\end{array}$ & $\begin{array}{l}9 \\
7.3 \%\end{array}$ & $1.8 \%$ & $\begin{array}{l}0 \\
.0 \%\end{array}$ & $\begin{array}{l}6 \\
4.8 \%\end{array}$ & $\begin{array}{l}2 \\
1.6 \%\end{array}$ & $\begin{array}{l}43 \\
34.7 \%\end{array}$ & $\begin{array}{l}124 \\
100.0 \%\end{array}$ \\
\hline Halkin Sesi & $\begin{array}{l}\text { Count } \\
\% \text { within } \mathrm{q} 1\end{array}$ & $\begin{array}{l}33 \\
47.8 \%\end{array}$ & $\begin{array}{l}3 \\
4.3 \%\end{array}$ & $\begin{array}{l}1 \\
1.4 \%\end{array}$ & $\begin{array}{l}0 \\
.0 \%\end{array}$ & $\begin{array}{l}2 \\
2.9 \%\end{array}$ & $\begin{array}{l}2 \\
2.9 \%\end{array}$ & $\begin{array}{l}28 \\
40.6 \%\end{array}$ & $\begin{array}{c}69 \\
100.0 \%\end{array}$ \\
\hline Yeni Duzen & $\begin{array}{l}\text { Count } \\
\% \text { within q1 }\end{array}$ & $\begin{array}{l}39 \\
42.9 \%\end{array}$ & $\begin{array}{l}8 \\
8.8 \%\end{array}$ & $0 \%$ & $\begin{array}{l}1 \\
1.1 \%\end{array}$ & $\begin{array}{l}7 \\
7.7 \%\end{array}$ & $\begin{array}{l}1 \\
1.1 \%\end{array}$ & $\begin{array}{l}35 \\
38.5 \%\end{array}$ & $\begin{array}{c}91 \\
100.0 \%\end{array}$ \\
\hline Volkan & $\begin{array}{l}\text { Count } \\
\% \text { within q1 }\end{array}$ & $\begin{array}{l}55 \\
53.4 \% \\
\end{array}$ & $\begin{array}{l}8 \\
7.7 \% \\
\end{array}$ & $\begin{array}{l}2 \\
1.9 \% \\
\end{array}$ & $\begin{array}{l}3 \\
2.9 \% \\
\end{array}$ & $\begin{array}{l}2 \\
1.9 \% \\
\end{array}$ & $\begin{array}{l}2 \\
1.9 \% \\
\end{array}$ & $\begin{array}{l}31 \\
30.1 \% \\
\end{array}$ & $\begin{array}{l}103 \\
100.0 \%\end{array}$ \\
\hline Afrika & $\begin{array}{l}\text { Count } \\
\% \text { within q1 }\end{array}$ & $\begin{array}{l}21 \\
35.6 \%\end{array}$ & $\begin{array}{l}5 \\
8.8 \%\end{array}$ & $\begin{array}{l}1 \\
1.7 \%\end{array}$ & $\begin{array}{l}1 \\
1.7 \%\end{array}$ & $\begin{array}{l}4 \\
6.8 \%\end{array}$ & $\begin{array}{l}0 \\
.0 \%\end{array}$ & $\begin{array}{l}27 \\
45.8 \%\end{array}$ & $\begin{array}{c}59 \\
100.0 \%\end{array}$ \\
\hline Total & $\begin{array}{l}\text { Count } \\
\% \text { within q1 }\end{array}$ & $\begin{array}{l}211 \\
47.3 \%\end{array}$ & $\begin{array}{l}33 \\
7.4 \%\end{array}$ & $\begin{array}{l}5 \\
1.1 \%\end{array}$ & $\begin{array}{l}5 \\
1.1 \%\end{array}$ & $\begin{array}{l}21 \\
4.7 \%\end{array}$ & $\begin{array}{l}7 \\
1.6 \%\end{array}$ & $\begin{array}{l}164 \\
36.8 \%\end{array}$ & $\begin{array}{l}446 \\
100.0 \%\end{array}$ \\
\hline
\end{tabular}

Article topics within Turkish Cypriot newspapers on the Cyprus Conflict, Greece, or Greek Cypriots. 
RQ3: "The news values of Cypriot journalism are not helping with reconciliation and peace building between the Turkish and the Greek Cypriot communities."

Once we examine the responses given to the first and second hypotheses, we can see that the issue of news values in the Cypriot media is problematic from the perspective of Peace Journalism. There are many traditional news values that help the media worker decide which news story to cover. It is important to stress that, "the criteria journalists use for selecting the news [news values] vary from one culture to another, reflecting various ideological, political, and cultural realities." ${ }^{16}$ Some criteria can be different from one culture to another, but study results show that there are basic news values that journalists follow.

The baseline study of news values was done by Galtung and Ruge. ${ }^{57}$ According to them, there are nine factors that influence the flow of news. The nine factors are: time span; intensity or threshold value; clarity/lack of ambiguity; cultural proximity or relevance; consonance; unexpectedness; continuity; composition; and socio cultural values. All these factors affect the news selection process.

It is not fair to criticize only the Cypriot media for having problematic news values. Any time the above-mentioned news values are used actively in a conflict zone, there will certainly be problems in terms of Peace Journalism.

For instance, as confirmed by the responses given to the second hypothesis question, the Cypriot media has the tendency to portray the Other as evil by reporting negative stories about them. Taking into account the study conducted by Galtung and Ruge on the concept of news values, it becomes clear that "negativity, sensationalism and unexpectedness" are among the themes that are widely pursued by the Cypriot media. Negative, sensational and unexpected stories do not pose such crucial problems when reported in a country free of conflict. However, if negative, sensational and unexpected stories about the Other are repeatedly covered in places like Cyprus or Israel and Palestine, it gives rise to feelings of antipathy from the community. It is useful to recall the following: "We should always remember that the media do not make peace, but they can positively contribute to it." ${ }^{\text {8 }}$ Media cannot bring peace in its own right, but can make a significant contribution. Such a contribution can be made possible only through practicing responsible reporting and allocating more space to empathy while covering news about the Other.

The message of the paper, however, should not be misunderstood; it is not argued that one should always portray the world through rose-colored glasses or only report stories about peace. This is the last thing Peace Journalism advocates. If there is a problem, naturally, it should be reported. However, a story about the drugs in South Cyprus should not be portrayed from the perspective of "us" and "them." In other words, a news story which is framed as "You see, there is this drug dealing in South Cyprus; they are evil and we are good" will neither contribute to a solution on the island nor to a sustainable peace process.

Elite-centred news is deemed more valuable in traditional journalism, but a peace deal that is accepted solely by the elite will hardly be a sustainable one. It is necessary 
to engage communities and civil society in such a process. Unfortunately, as is clear from the responses given to the first hypothesis question, elite-centred news reporting is what dominates the Cypriot media.

The third hypothesis tested in this study, which reads "The news values of Cypriot journalism are not belping with the reconciliation and peace building between the Turkish and the Greek Cypriot communities" is, unfortunately, true and is supported by the studies herein, when considered together with the results of the first and second hypotheses.

\section{Discussion}

The results of this study reveal that Turkish and Greek Cypriot newspapers operating in Cyprus practice traditional journalism and have not yet started practicing responsible reporting and selecting news values relevant to Peace Journalism. Journalists who believe in Peace Journalism are either not able to practice it or are not informed properly about the concept itself.

All three hypotheses used in this study are proven to hold true for the Cypriot media. It can be consequently stated that Turkish and Greek Cypriot newspapers make use of negative expressions in their headlines when covering news stories about one another. Under these circumstances, given the fact that news agencies are busy smearing each other, a possible positive contribution to the peace process by the media cannot be expected.

During the conflict resolution process, media coverage of conflict is an important factor. For instance, the most prominent peace researcher and Peace Journalism founder Johan Galtung suggests that a Peace Journalism frame, rather than a war journalism frame, should be utilized by the media during times of conflict. His classification of war journalism and Peace Journalism is based on four broad practices and linguistic orientations: "peace/conflict, truth, people, and solutions. In contrast, war journalism is oriented in war/violence, propaganda, elites, and victory." 59

Choice of wording and their organizations into news is important, especially, in reporting the conflict process. The media has a great responsibility to choose the words and set the agenda for discussion. Gregory Kent gives an example from the Bosnian war on media framing, "'Media framing,' in essence, the underlying language, key terms, labels and phrases used to describe events, played a critical role in establishing how the actual problem of Bosnia came to be defined, particularly through selection of language and decisions about balancing and what kinds of evidence would be reported. The resultant framing, by obfuscating important issues about responsibility for the war and the manner in which it was conducted, limited potential policy options to ineffectual and inappropriate options." 60

\section{Conclusion}

This study presents definitive evidence that news coverage in Cyprus does not contribute to peace building. In light of the renewed negotiations in Cyprus for 
reunification, the Cypriot media should engage in responsible reporting. It is of utmost importance that Peace Journalism is introduced and supported in Cyprus now.

There is a prevailing perception among journalists that as "I write the report, I don't care about the rest" or "My business is news reporting, don't put additional burdens on my shoulders." Traditional journalists should first of all accept the fact that their practice of news reporting is problematic. It is not possible to come up with a solution to a problem without first acknowledging that there is a problem.

Many journalists do not bother allowing room for statements of the parties facing incrimination in a news story, nor do they bother about enriching their news sources. Likewise, most journalists abide by state and government oriented news reporting, thus only considering the statements made by state authorities as stories having news value. They tend to report only the apparent or visible parts of a story or the action itself. In other words, most do not make an effort to do process-based and investigative reporting that also reveal the invisible parts of the story. Doing research and seeking to uncover the invisible entails arduous work and takes time.

With the advent of technology and the industrialization and monopolization of the media, it has gained a new structure in which news agencies compete with one another and do anything they can to dodge their rivals. Within this framework, journalists who continue racing against each other sacrifice the quality of their news for the sake of being the first to report the news story and discard other news agencies - journalists report news that is incomplete, ordinary, lacking information and covered in a partial manner. Peace Journalism is an alternative for the media.

In conclusion, all novelty faces resistance; this also holds true for the concept of Peace Journalism. People have always been prejudiced against the act of changing and change itself. A majority of journalists in Cyprus are not willing to overturn the existing mechanism, nor willing to exert the effort or show any inclination to do so.

The scope of this study was to investigate the role of the media in the Cyprus Conflict using headlines of the published papers over the last 2 years. It is proven that there are severe problems there from the perspective of Peace Journalism.

\section{Appendix Evaluation of the Headlines}

\section{POSITIVE (TOWARDS THE OTHER)}

1. "Inclusive" Frame

2. "Solution Oriented" Frame

3. "Understanding the Other" Frame

4. "Forgiveness" Frame

5. "Empathy" Frame

6. "Trust" Frame

7. "Unprejudiced" Frame

8. "Fair Play" Frame

9. "Balance Background" Frame

10. "Self Reflexive Criticism of Government Policy" Frame 
11. "Emphasize Both Sides' Pains" Frame

12. "We are Friends" Frame

13. "Win-Win" Frame

14. "Accept Other As It Is" Frame

15. "Anti-nationalist" Frame

16. "History - Culture" Frame

17. "Friendly Speech" Frame

18. "Applaud" Frame

19. "Other in the Self" Frame

20. "Common Ground" Frame

21. "Good/Good or Bad/Bad" Frame

\section{NEGATIVE (TOWARDS THE OTHER)}

1. "Exclusive" Frame

2. "Status Quo Oriented" Frame

3. "The Other is the Threat" Frame

4. "Revenge" Frame.

5. "Antipathy" Frame

6. "Distrust" Frame

7. "Prejudiced" Frame

8. "Sport" Frame

9. "Unbalance Background" Frame

10. "Criticize the Other Side's Government Policy" Frame

11. "Emphasize One Side's Pains" Frame

12. "They are our Enemy" Frame

13. "Win-Lose" Frame

14. "Inferior" Frame

15. "Nationalist" Frame

16. "Who Throw The First Stone" Frame

17. "Hate Speech" Frame

18. "Blame" Frame

19. "Self and Other" Frame

20. "Just War" Frame

21. "Good and Evil" Frame

\section{NEUTRAL (DESCRIPTIVE)}

1. Just describes what happened without passing judgement.

2. Transfers the information without questioning it.

3. Provides direct quotation in the headline from the source of the story.

\section{Endnotes}

1. Ahmet Sozen, "Cyprus Conflict: Continuing Challenges and Prospects for Resolution in the post-Cold War Era," Ph.D. thesis, University of Missouri-Columbia, (1999), 1. 
2. The Cyprus Conflict is known to have arisen after the lending of the island to Great Britain. As the Ottoman Empire got weaker in the 19th century, Britain leased the island in 1878. The British rule from 1878 to 1959 has harbored some deep-rooted causes that eventually led to the Cyprus Conflict. Great Britain wanted to keep Cyprus as its colony at any cost and was merciless enough to enforce its "divide and rule" policy, which created hostilities among the two communities, Niyazi Kizilyurek, Kibris Sorununda Ic ve Dis Etmenler (Lefkosa: Isik Kitap Evi, 2001), 32." The island's falling under the British Rule was initially hailed by those Greek Cypriots who aspired to ENOSIS (union with Greece). However, the British Rule was not positive about the Greek Cypriot's demand for ENOSIS and accordingly took some measures against such an outcome. Winning the support of Turkish Cypriots was one of the measures bearing importance. The Brits made Turkish Cypriots believe in the fact that they would lose their rights as Muslim Turks if the British colonial rule in the island ceased to exist, thus hurling Turkish Cypriots and Greek Cypriots into the fray of a conflict that would last for many years. To realize their aspiration for ENOSIS, the Greek Cypriots formed the organisation EOKA (Ethniki Organosis Kyprion Agoniston: National Organisation for Cypriot Struggle) in 1952 under the leadership of Archbishop Makarios. On 1 April 1955, EOKA staged its first armed attack against the British rule. "The British Administration took a set of measures against the acts of EOKA ... The British Rule put into place its most powerful weapon: the 'DIVIDE and RULE' policy. It employed Turkish Cypriot police officers to counter EOKA activists and tried to create a divide between the two communities, Niyazi Kizilyurek, Kibris Sorununda Ic ve Dis Etmenler (Lefkosa: Isik Kitap Evi, 2001), 51.” All those attacks, originally targeting British rule, later on turned into attacks flaming ethnic clashes, following the intervention of the Turkish Cypriots in the capacity of Auxiliary police officers. The Turkish Cypriot community staged counter offensives in revenge for the Auxiliary Turkish Cypriot police officers who were killed in those attacks, serving the objectives of the British administration. Once the clashes between the two communities of the island reached a critical point, Turkish Cypriots started TMT (Turkish Resistance Organisation) on 1 August 1958. "TMT remained an underground organisation from 1 August 1958 till 21 December 1963, during which it got organized, trained its members, possessed arms and prepared itself for any potential attack of Greek Cypriots, Ismail Tansu, Aslinda Hic Kimse Uyumuyordu (Ankara: Minpa Matbaacilik ve Tic. Ltd. Sti., 2001), 15." Given that, things developed in the direction desired by the British and Greek Cypriots started to perceive Turkish Cypriots -in addition to the British - as an obstacle to their aspiration for ENOSIS. Britain planned its next move. As a result of the British "Divide and Rule" policy, the idea of TAKSIM (partition) was put forward as a response to ENOSIS. The Brits worked hard to force Turkish Cypriots' to adopt the idea of a divide, a partition instead of island's union with Greece. The divided interests forcibly created in the two communities have only brought about deaths, casualties, missing people, orphans, poverty, misery and migration. The Cyprus Conflict has remained unresolved for more than fifty years, still having negative implications for both communities.

3. Daya K. Thussu and Des Freedman, War and the Media, (London: Sage Publications Ltd., 2003): 5 .

4. Gadi Wolfsfeld, Media and the Path to Peace, (UK: Cambridge University Press, 2004), 75.

5. Ibid, 159.

6. Ibid, 220 .

7. See, Lea Mandelzis, "Representation of Peace in News Discourse: Viewpoint and Opportunity for Peace Journalism," Conflict and Communication Online, Vol. 6, No. 1, (2007). Edward S. Herman and Noam Chomsky, Manufacturing Consent: The Political Economy of the Mass Media, (New York: Pantheon Books, 1988). Gadi Wolfsfeld and Rami Khouri and Yoram Peri, "News About the Other in Jordan and Israel: Does Peace Make a Difference," Political Communication, Taylor $\&$ Francis, (2002). Herbert J. Gans, Deciding What's News: A Study of CBS Evening News, NBC Nightly News, News Week and Times, (Illinois: Northwestern University Press, 1979). Pamela J. Shoemaker and Stephen D. Reese, Mediating the Message, (USA: Second Edition, Longman Publishers, 1996). Gadi Wolfseld, Media and Political Conflict: News from the Middle East, (Cambridge: Cambridge 
University Press, 1997). Jake Lynch, "What's so great about Peace Journalism?," Global Media Journal: Mediterranean Edition 1(1) (2006).

8. Metin Ersoy, "Obstacles to Peace Journalism in North Cyprus," Global Media Journal: Mediterranean Edition, 1(2) Fall, (2006), 75.

9. Annabel McGoldrick and Jake Lynch, "Peace Journalism, an interview with Johan Galtung," Reporting the World, (2005). http://www.bigpicture.tv/videos/watch/b73ce398c.

10. The author of this article asked Johan Galtung for his rationale for using the term "Peace Journalism" by email in 2008. Johan Galtung answers this question showing two major reasons: "[1] This was during the Cold War, and I wanted to make my little contribution to the legitimacy of the word 'peace.' The East used it a lot, so the West, particularly USA-UK thought they had to be against it. Their approach was to see peace as suspect, even subversive, and they always added something, like peace with freedom, peace with justice; leaving peace undefined. Or by leaving the difficult word out, talking of conflict studies, international studies, etc. and they still do that - not saying that those studies are not good in themselves. But I wanted to give 'peace' more meaning, more content, by linking it to other, less problematic, concepts. Hence 'peace research'-and there were strong reactions against it. The link 'peace and conflict research' was actually invented by me January 1959 as the two are intrinsically connected, at least for negative peace: handle conflict without violence (but also for positive peace: handle cooperation at ever higher levels). I stuck to the word 'peace' and added adjectives like negative, positive, and then used it as an adjective in peace research, peace journalism and now peace business. There is more to come, always keeping the word peace in it."

[2] "Less semantic, philosophical, more pragmatic political: there is an implicit program in peace research, peace journalism, peace business. I found peace unexplored by academics as opposed to war studies, which focused on victory, journalism focused on violence and business on profit. Not good enough. During my years at Columbia University, New York, 1957-60 the US pragmatism in always asking 'what can we do about it' impressed me. A strong feeling that there were jobs to be done, we put a marker on it and learn as we go."

11. Ibid.

12. Johan Galtung, Peace by Peaceful Means: Peace and Conflict, Development and Civilization, (London: Sage, 1996).

13. Metin Ersoy. Ibid, 69.

14. See Johan Galtung, "The Peace Journalism Option," Conflict \& Peace Forums, (1998). Johan Galtung, "High Road, Low Road," [article on-line] Track Two. 7, no. 4, (1998). (accessed on 15 October 2009); available at http://ccrweb.ccr.uct.ac.za/archive/two/7_4/p07_highroad_lowroad.html. Johan Galtung, "Peace Journalism - A Challenge," in Journalism and the New World Order, Vol. II, Studying War and the Media, Kempf, W. and Luostarinen, H., (eds.) (Goteborg: Nordicom, 2002).

15. Wilhelm Kempf, "Konfliktberichterstattung zwischen Eskalation und Deeskalation. Ein sozialpsychologisches Modell. (Wissenschaft und Frieden), 14, (1996). Wilhelm Kempf, "Conflict Coverage and Conflict Escalation" in: Kempf, Wilhelm \& Heikki Loustarinen (eds) Journalism and the New World Order, Vol. II, Studying the War and the Media, (Gothenburg: Nordicom, 2002).

16. Dov Shinar, "Peace Processes in Cultural Conflict: The Role of the Media," Conflict and Communication Online, 2:1, (2003).

17. Austrian Study Center for Peace and Conflict Resolution (ed.) Constructive Conflict Coverage. A Social Psychological Approach, (Berlin: Regener, 2003).

18. Jake Lynch and Annabel McGoldrick, Peace Journalism, (UK: Hawthorn Press, 2005).

19. Cited in Susan D. Ross, "(De)Constructing Conflict: A Focused Review of War and Peace Journalism," Conflict and Communication Online, Vol. 5, No. 2, (2006), 4.

20. Johan Galtung, Peace Professor and Director of the TRANSCEND Peace and Development Network. (www.transcend.org).

21. Johan Galtung, "Peace Journalism - A Challenge," in Journalism and the New World Order, eds. Kempf, W. and Luostarinen, H., (Goteborg: Nordicom, Vol. II, studying war and the media, 2002), 5 . 
22. Ibid.

23. Dov Shinar, "Peace Journalism: Promise and Performance," a paper presented at the International Conference "From Conflict to Peace in the Public Sphere: Peace Education, Media and Discourse" (June 18-20, 2006), The Smart Institute, The Hebrew University of Jerusalem, Israel, (2006).

24. Jake Lynch and Annabel McGoldrick, 2005. Ibid.

25. Wilhelm Kempf, "Constructive conflict coverage — A social-psychological research and development program," Conflict E Communication Online, Vol. 2, No. 2, (2003).

26. Pavel Bandakov, "Other's Wars around Us. Understanding the Attitudes of Russian Audience towards War A Journalist Approach" unpublished paper was presented in IPRA conference (2006).

27. Dov Shinar, "Epilogue: Peace Journalism — The State of the Art," Conflict and Communication Online, Vol. 6, No. 1, (2007a).

28. Johan Galtung, "Peace Journalism as an Ethical Challenge," Global Media Journal: Mediterranean Edition, 1(2) Fall, (2006), 5.

29. Ibid.

30. Annabel McGoldrick and Jake Lynch, "Peace Journalism: What is it?, How To Do It?" Reporting the World, (2000), 22.

31. Sevda Alankuş, Gazetecilik ve Habercilik, Habercinin El Kitabı Dizisi: 4, (İstanbul: IPS İletişim Vakfı Yayınları: 7, 2003).

32. Kathleen H. Jamieson and Karlyn K. Campbell, The Interplay of Influence: Mass Media $\&$ Their Publics in News, Advertising, Politics, (California: Wadsworth Publishing Company, 1982), 16.

33. Herbert J. Gans, Deciding What's News: A Study of CBS Evening News, NBC Nightly News, News Week and Times, (Illinois: Northwestern University Press, 1979), 39.

34. Johan Galtung, 2006. Ibid, 5.

35. Jake Lynch and Annabel McGoldrick 2005. Ibid, 5, 224.

36. Johan Galtung 2002. Ibid, 5.

37. The term Gatekeeping in communication literature is conceived mainly as a selection process. The literature treats the gatekeeper in a similar way to Lewin's concept where it is applied to both interpersonal and mass communication (cited in Karine Barzilai-Nahon, "Toward a theory of network gatekeeping: A framework for exploring information control," Journal of the American Society for Information Science and Technology, Volume 59, Issue 9, (2008), 3.

38. Johan Galtung and Richard C. Vincent, Global Glasnost: Toward a New World and Communication Order?, (Hampton Press, 1992), 5.

39. Dov Shinar, "Democracy, Development, Peace and Communication: An Overview of their Roles and Interaction," Global Media Journal: Mediterranean Edition 2(1) Spring (2007b), 56.

40. Ibid.

41. Wilhelm Kempf, "Acceptance and impact of de-escalation conflict coverage," Diskussionsbeitrage der Projektgruppe Friedensforschung Konstanz, Nr. 60, (2006).

42. Cited in Wilhelm Kempf, 2006. Ibid, 3.

43. Roger Fowler, Language in the News: Discourse and Ideology in the Press, (London: Routledge and Kegan Paul, 1991).

44. Jake Lynch, "What's so great about Peace Journalism?," Global Media Journal: Mediterranean Edition 1(1) (2006), 74.

45. Ibid.

46. Esra D. Arsan, "Catisma ve Savas Donemlerinde Gazetecilik," in Gazetecilik ve Habercilik, Habercinin El Kitabı Dizisi: 4, ed. Alankuş, Sevda (Istanbul: IPS İletişim Vakfı Yayınları: 7, 2003), 51-52.

47. Ibid.

48. Lesley Fordred Green and Phillip Visser, unpublished notes for a lecture on media anthropology, South Africa: University of Cape Town, (2000).

49. Ibid.

50. Ibid.

51. Ibid. 
52. Ibid.

53. The list of the headline evaluation is provided in the Appendix.

54. Gadi Wolfsfeld, 2004. Ibid, 9.

55. See Wilhelm Kempf, 2006. Ibid.

56. Noha Mellor, The Making of Arab News (New York: Rowman \& Littlefield Publishers, Inc., 2005), 75.

57. Johan Galtung and Mari H. Ruge, "The Structure of Foreign News. The Presentation of the Congo, Cuba and Cyprus Crises in Four Norwegian Newspapers," Journal of Peace Research, vol. 2, (1965), 64-91.

58. Suleyman Irvan, "Peace Journalism as a Normative Theory: Premises and Obstacles," Global Media Journal: Mediterranean Edition 1(2) Fall, (2006), 37.

59. Crispin C. Maslog and Seow T. Lee, "War or Peace Journalism? Asian Newspaper Coverage of Conflicts," Journal of Communication, (2005): 314.

60. Gregory Kent, "Humanitarian agencies, media and the war against Bosnia: 'neutrality' and framing moral equalisation in a genocidal war of expansion", Journal of Humanitarian Assistance, (2003), 3. 